\title{
THE IMPACT OF DIGITAL LEARNING MODULE IN IMPROVING STUDENTS' PROBLEM-SOLVING SKILLS
}

\author{
Diah Mulhayatiah*1, Purwanti ${ }^{2}$, Winda Setya ${ }^{3}$, Herni Yuniarti Suhendi ${ }^{4}$, Rahayu \\ Kariadinata $^{5}$, Sri Hartini ${ }^{6}$ \\ 1, 2,3,4 Physics Education Study Program, UIN Sunan Gunung Djati, Bandung, Indonesia \\ ${ }^{5}$ Mathematics Education Study Program, UIN Sunan Gunung Djati, Bandung, Indonesia \\ ${ }^{6}$ Physics Education Study Program, Lambung Mangkurat University, Banjarmasin, Indonesia \\ *Correspondence address: diahmulhayatiah@uinsgd.ac.id
}

Received: October 27 $7^{\text {th }}$ 2018. Accepted: April $4^{\text {th }}$, 2019. Published: April 29 2019

\begin{abstract}
This study aims to determine the improvement of problem-solving skills using problem-based digital learning module. The research method used is quasi-experiment design with non-equivalent control group design. The sampling technique used is the purposive sampling of 60 subjects with 30 for the experimental class and 30 for the control class. The research result indicates the learning process both classes runs well. It is proven by the significance of the hypothesis test result which is less than $\alpha(0,005)<$ $0,05)$. It can be concluded that Ha is accepted and Ho is rejected. It means that there are differences in students' problem-solving skills in the experiment class and control class. This proves the treatment in the experimental class using problem-based digital learning module integrated with religious values can influence students' problem-solving skills better than the PowerPoint learning media used in the control class.
\end{abstract}

() 2019 Physics Education, UIN Raden Intan Lampung, Indonesia

Keywords: higher-order thinking, digital media, problem based learning module

\section{INTRODUCTION}

Education is meant to prepare human resources to acquire knowledge, technology, and skills. So, $21^{\text {st }}$-century education has a very important role in preparing the next generation to be able to compete in a globalized world. Mayasari, Kadarohman dan Rusdiana says that the role of education in the $21^{\text {st }}$ century is becoming important to prepare the next generation to have some skills including learning and innovating skills, skills in using technology, the media and information, as well as being able to work and survive through skills (Mayasari, Kadarohman, \& Rusdiana, 2016).

The education program in the $21^{\text {st }}$ century has been forced to undergo significant changes. One of the changes is the transformation from an industrial society into a learning society (Malik, 2015). Reveals that to face these changes, the concept of learning principles should be constructed to support universal education. The changes made by the reforming of the learning process. This reformation is seen as an effort in realizing the situation and process of the learning in accordance with the established standards (Häkkinen et al., 2017). To reform the learning, the Government through the Regulation of the Ministry of National Education No. 23 of 2006 has set a standard competency of graduates for Senior High School that requires someone to be able to develop and apply information and knowledge in a logical, creative, innovative, and able to show the ability of logical thinking and decisionmaking (Kemendikbud, 2006). This is the standard that correlates to the $21^{\text {st }}$-century skills. One of the competencies of the $21^{\text {st }}$ century is a problem-solving skill (Christoyadi, Widoretno, \& Karyanto, 2016). Problem-solving skill is the ability of a person to find a solution through a 
search process that involves the acquisition and organizing information to achieve a goal (Sujarwanto, 2014). The problemsolving ability owned by the students can be identified through the ability in organizing and using the knowledge, as well as connecting one concept with another when solving the problems (Gao, Liu, Xu, Cui, \& Lv, 2018).

Preliminary research results by interviewing the physics teacher of the eleventh grade of the science class acquired the learning outcomes indicated that problem-solving skill of the students was poor. Based on the learning outcome, it can be said that the students need innovation in the learning process. It can be caused by the method or learning media. Other data were obtained based on the analysis of the students' answers through a questionnaire. It was found that $100 \%$ of the students expressed the difficulty in learning physics, $68 \%$ of the students stated that the question asked by the teachers in test or learning process could not help them to increase the problemsolving skills. In addition, $71 \%$ of the student argues that learning physic helps them to make a solution with daily life problems. Based on the preliminary results research, the students were not skilled in resolving the question of physics especially associated with the problemsolving skills. This was indicated when the teacher gave the sample problems and exercises of the same type, but with one changed variable, the students had difficulty in completing it.

The cultivation of the students' problem-solving skills is still difficult because it is constrained by a learning resource or learning media (Akyuz, 2015; Häkkinen et al., 2017). The learning resources or learning media used by the teacher was module or textbook provided by the Government in a limited number of print. The modules or the textbook was sometimes not yet in accordance with competencies to be achieved by the student. So, the teachers were required to be creative in collecting learning resources and creating media needed (Nurhidayanti, Tayeb, \& Abbas, 2017). Nurjanah says that the success of the learning process depends on learning resources or learning media selected (Nurjanah, 2014). Munadi says the learning media is secondary resources learning besides the teacher that is connecting the module or learning resource to the student in different ways (Munadi, 2012).

The learning module is one of the printed and digital learning media. Learning modules can be used as a learning resource to accommodate students' higher-order thinking skills (Suhendi, Mulhayatiah, Yuningsih, et al., 2018). Learning modules are complete units to support the learning activities that are structured to assist students in achieving a number of objectives or competencies (Christoyadi et al., 2016; McClean, Attardi, Faden, \& Goldsmidt, 2016; Mirkouei, Bhinge, McCoy, Haapala, \& Dornfeld, 2016; Ruipérez-Valiente, Muñoz-Merino, Leony, \& Kloss, 2015). The use of the modules can drill the students' ways of thinking about the fact and relate them to other facts along with a logical reason. The use of modules in learning can help the student in solving problems independently (Christoyadi et al, 2016; Purnamawati, Ertikanto, \& Suyatna, 2017).

The digital modules are innovations that can be used by teachers in solving the problems of Government-issued module or textbook. These innovations can be done by utilizing the development of IT technology in schools. Arsyad stated that the development of science and technology is increased by utilizing technology in the teaching and learning process (Arsyad, 2013).

Learning modules used in the Islamic Senior High School (MA) and Senior High School (SMA) are ideally different. It caused by the major of the school where 
the MA's curriculum is integrated curriculum Islamic education. The results of the observations made by (Ali, Sunarno, \& Sukarmin, 2015) indicate that education in MA is still using the same learning modules as well as in the SMA, so there is no difference between MA and SMA. The learning modules being used has not been integrated with the Islamic values which correspond to the needs of the MA under the auspices of the Ministry of Religious Affairs. According to (Zakwandi, Zannah, \& Irawan; 2017) there are still very little learning modules integrated with Islamic values. Therefore, in carrying out the process of teaching and learning or to facilitate the students in learning, for example in the use of learning modules, it is necessary to integrate the Islamic values. The religious values of Islam can be embedded. Based on the revised edition of the Indonesian curriculum, it states that in achieving competencies, knowledge, and skills, it should be integrated with religious competences.

This research aims to develop a learning module integrated with Islamic values. The learning modules made is a digital module integrated with religious values containing the electromagnetic waves material. The content is selected based on diagnosis trouble in physics study performed by Marshman, Singh dan Rusilowati at the level of Elementary School, Junior High School, and Senior High School (Marshman \& Singh, 2015; Rusilowati, 2007). The physics content material that is deemed difficult is the wave. The weakness of the students in learning physics is structure ability, particularly the ability to use the concepts of knowledge and create a strategy for solving problems. It is caused by the lack of problem-solving skills while the problem-solving skills are a must-have skill in the $21^{\text {st }}$ century (Adams \& Wieman, 2015).

Based on the problems that have been described, the purpose of this research is to know 1) the learning outcome of the physics learning in the electromagnetic waves using problem-based digital learning modules integrated with religious values compared to the one that does not use problem-based digital learning modules integrated with religious values, 2) the improvement of problem-solving skills after using the problem-based digital learning modules integrated with religious values on the electromagnetic waves material, 3) the improvement of problemsolving skills of the students that do not use the problem-based digital learning modules integrated with religious values on the electromagnetic waves material, and 4) to compare the problem-solving ability improvement of the students that use the problem-based digital learning modules integrated with religious values on the electromagnetic waves material and those who don't.

\section{METHOD}

This research was conducted using the experimental method with a quasiexperimental design. The quasiexperimental design used in this study is the nonequivalent control group design. The samples of the research were 60 students, with 30 students in of the eleventh grade of science major 2 class as the experimental class and 30 students of the eleventh grade of science major 1 class as the control class. The sample was determined using the purposive sampling technique by considering its homogeneity of the students' ability (No superior class system). The research instruments used consisted of validation sheet of learning media, observation sheets of learning achievement, questionnaires for student responses, and problem-solving ability test. These validation sheets were given to one material expert, one media expert, and one physics teachers. Score from each expert was calculated using a Likert scale and was categorized into $90<\mathrm{P} \leq 100$, the category of a high score is $70<\mathrm{P} \leq 90$, the 
category of a moderate score is $50<\mathrm{P} \leq 70$, and the poor category is $<50$ (Kemendikbud, 2010).

The data from the observation sheet was processed by calculating the percentage of learning achievement using the following equation (Ngalim, 2008).

$$
P(\%)=\frac{\sum \text { Learning Achievment Process }}{\sum \text { Stage of Learning Process }} \times 100 \%
$$

The next stage, the inclusion of categories of the learning achievement percentage obtained into the following category (Ngalim, 2008),

Table 1. Interpretation of the Learning Process

\begin{tabular}{ccc}
\hline No & Interval (\%) & Interpretation \\
\hline 1 & $0<\mathrm{P} \leq 55$ & Poor \\
2 & $55<\mathrm{P} \leq 59$ & Low \\
3 & $59<\mathrm{P} \leq 75$ & Moderate \\
4 & $75<\mathrm{P} \leq 85$ & High \\
5 & $85<\mathrm{P} \leq 100$ & Excellent \\
\hline
\end{tabular}

The questionnaire was made to know the extent of the impact of the developed product toward the students' ability in connecting the physics concepts with Islamic values that can be applied to daily life. The data obtained were analyzed by using the following equation (Lomax, 2000).

$$
K=\frac{\sum n_{i}}{N} \times 100 \%
$$

The results of the calculations would then be categorized into excellent category for the interval of $84 \%<\mathrm{P} \leq 100 \%$, high category for the interval of $69 \%<\mathrm{P} \leq 84 \%$, moderate category for the interval of $54 \%<$ $\mathrm{P} \leq 69 \%$, low category for the interval of $39 \%<\mathrm{P} \leq 54 \%$, and the poor category for the interval of $0 \%<\mathrm{P} \leq 39 \%$ (Artina $\mathrm{Jr}, \mathrm{La}$ Rochelle, Dezee, \& Gehlbach, 2014; Myerson, Baumann, Ana, \& Green, 2014).

The analysis of the learning instruments in the form of problem-solving ability began with the drafting of the problem- solving question based on problem-solving indicators test. The stages of the problemsolving process are referring to the stages of problem-solving indicators according to Doctor et al. (2016) which consists of five phases, namely the description of a useful concept, approach to physics, the specific application of physics, mathematical usage precision, and logical progression. The data for this stage was analyzed through its problem-solving test including validation, reliability, difficulty level, and the differentiator by using the Anatest Version V4 program. The data from pre-test and post-test were analyzed through several stages, namely analyzing the learning outcome and the increase in the problemsolving skills by using the following equation (Hake, 2002).

$$
\text { Skor }=\frac{\sum \text { Student Score }}{\sum \text { Maximum score }} \times 100 \%
$$

The N-Gain value was calculated to know the increase in students' problem-solving skills by using the following equation (Hake, 2002).

$$
<g>=\frac{\text { posttestscore }- \text { pretestscore }}{\max \text { imumscore }- \text { pretestscore }}
$$

The value of $\mathrm{N}$-Gain obtained was categorized into multiple categories, the high category is $\mathrm{d}>0.7$, the moderate category is $0.30<\mathrm{d}<0.70$, and the low category is $d<0.30$ (Hake, 2002).

Hypothesis testing was conducted to find out the difference between experimental class and class control. The hypothesis test was done using the SPSS version 16 program.

\section{RESULTS AND DISCUSSION}

\section{Learning Module Validation}

The field of education is related to the validation process. One of the aspects is the instrument of the test for students' learning outcome. An instrument can be 
said to be well validated if the instrument can measure what it wants to measure (Suhendi, Ramdhani, \& Irwansyah, 2018). Validation performed covered the content aspects, linguistic aspects, layout aspects, and graphic aspects like the quality of picture and media. The validation results of the experts and teacher are presented in figure 1.

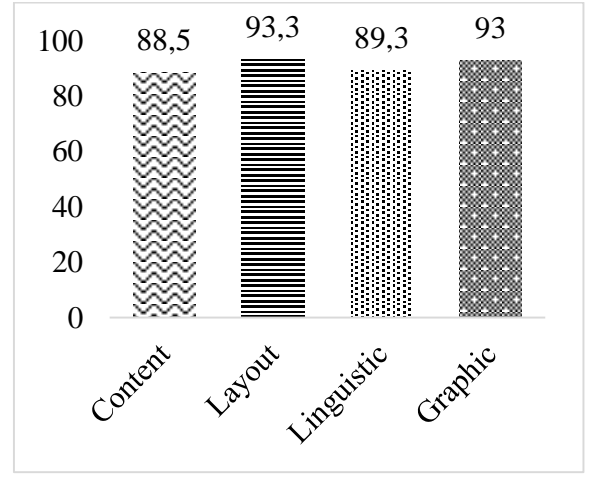

Figure 1. The Average Score of Validation

Based on the results of the validation, it was known that the developed module was valid to be used in learning because the overall average score obtained was 91.02 which belonged to the excellent eligibility criteria. The developed digital module that had been validated was stored in the exe format on CD and micro SD Flash to make it easy to copy and use on different computers or laptops as what had been done in the research of (Nurjanah, 2014). This digital module facilitates the students to learn independently and accommodates varying levels of students' learning speed. The students who have a high learning speed can learn faster and finish quicker. This is in accordance with the purpose of making a module according to (Prastowo, 2012).

Some of the features shown in the module are presented in figure $2-6$.

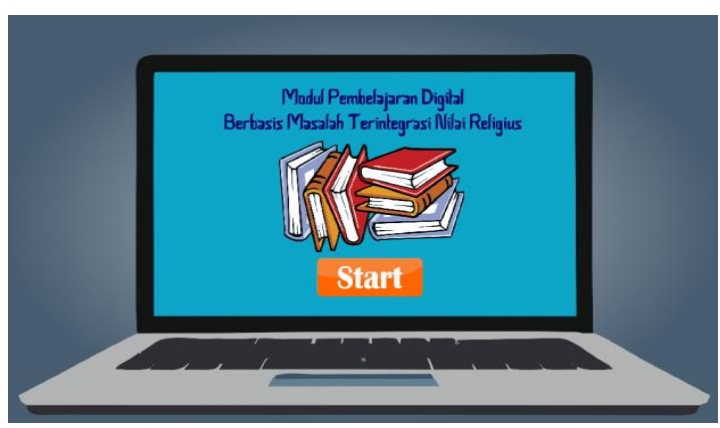

Figure 2. The Splash Screen of the Digital Modules

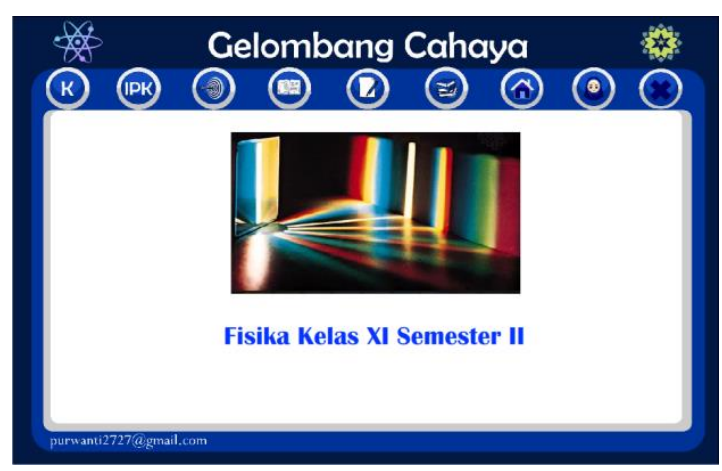

Figure 3. The Main Menu of the Digital Modules

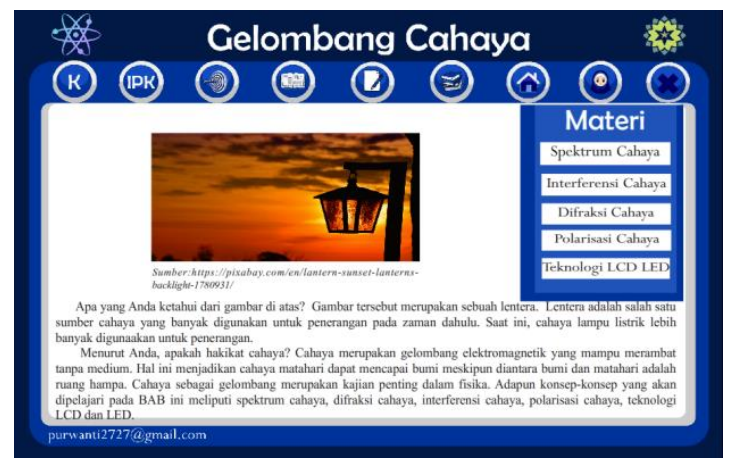

Figure 4. The Content Display

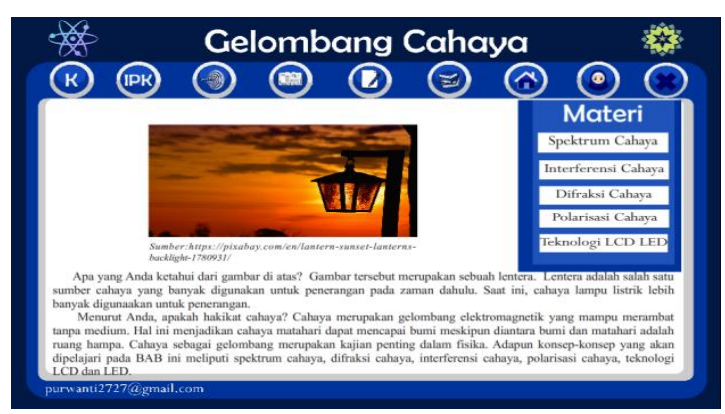

Figure 5. The Video on the Module as a Stimulation of Problem-Solving Skills 


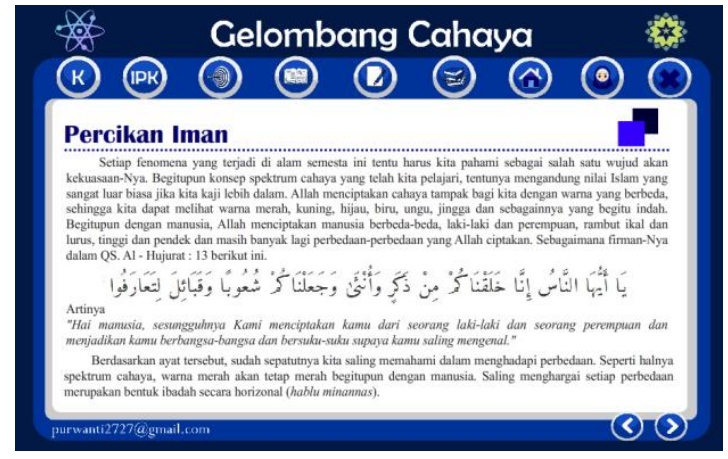

Figure 6. The Religious Content

\section{Learning Achievement of Experiment Class}

In the first application, the students were still confused about using the digital module. This was caused by the students' limited knowledge in navigating the menu and features provided in the digital module. The learning activity in the first meeting was not optimum especially on the closing activity. The question and answer session, the conclusions, and evaluations were constrained by time. However, the percentage of the learning was excellent on the value of $88.57 \%$ and the students could operate well on the value of $77.50 \%$.

There was an improvement in the second meeting. The students had known the buttons menu and features of the digital modules so that when the teacher instructed the students to observe the video or analyzing problems, the students operate the digital module with ease. In this meeting, the learning achievement value was $90.67 \%$ in the excellent category, and the students' activity has well categories with a percentage of $77.86 \%$. The next meeting, the student began to get used to the digital module. This was shown by the learning achievement value of $95.64 \%$ and $90.43 \%$ for the students' activity. In the fourth meeting, the students had become accustomed to carrying out learning with the digital module. Teachers could easily manage the classroom because the students already understood the flow of learning. In this meeting, the learning achievement was $90.45 \%$ for the teacher activity and $90.43 \%$ of student activity. A decrease in the percentage of the teacher's activity occurred at the fourth meeting with the decreased value of $5.19 \%$. The decrease was due to the use of a digital module that can direct the students' attention to be more motivated to learn before being instructed by the teacher. So, the teacher was more relax and easy to control the class. This corresponds to the benefit of the learning media according to (Arsyad, 2013). In the fifth meeting, the students were guided and directed to construct their knowledge through information retrieval from several sources of learning. The students must collect as many references from relevant sources. The learning achievement percentage was $97.71 \%$ of teacher activity and $86.86 \%$ of student activity.

Generally, learning achievement using the developed module, in their entirety, was carried out smoothly. Based on the analysis, the developed module can facilitate the students to be independent, substitute the function of the teacher in delivering the learning material, and as a source of learning to the student. This is in accordance with the function modules according to (Fhadhila, Ertikanto, \& Rosidin, 2018; Li, 2016).

\section{Learning Achievement of Control Class}

In the first meeting, the teacher was having difficulty customizing the student. Learning achievement in the first meeting was $75.17 \%$ of teacher's activity which belonged to the moderate category and $65.71 \%$ for students' activity which belonged to the high category. The next meeting was done by playing the video and PowerPoint presentation. However, it was not better than before with the learning achievement of $81.43 \%$ for teacher's activity which belonged to the high category and $74.71 \%$ for students' activity 
which belonged to the moderate categories.

The third meeting of the learning increased significantly compared to the first and second meeting. The students started to understand the flow of learning so that teachers could easily customize the student. This is shown by the value of the teacher's activity that reached $91.48 \%$ in the excellent category and $82.71 \%$ for students' activity with the high category. The fourth and fifth meetings were carried well. This reason is based to the learning achievement in the fourth meeting on learning for teacher's activity that reached $95.9 \%$ and $88.9 \%$ for students' activity and in the fourth meeting and the teacher's activity reached $99.29 \%$ while the student's activity reached $93.07 \%$ in the fifth meeting. Generally, the learning by using the PowerPoint media experienced significant improvement at each meeting.

\section{The Students' Responses}

The result of the analysis of the students' response toward the learning module obtained an average score of 88.48. This response indicated that the students were in the excellent category (Asyhari \& Silvia, 2016; Irwandani, Latifah, Asyhari, Muzannur, \& Widayanti, 2017). The student assessed that content and the religious values were presented based on the daily life phenomena.

The digital module used by the student in the study has several benefits. Among others, the digital module facilitates students in learning and understanding the material of the electromagnetic wave. The students are accustomed to relating the concept of physics with religious values that can be retrieved from that concept. Other benefits that can be obtained from the use of the digital modules, i.e., the student is able to adapt to the environment and to apply religious values with the studied concepts of Physics in everyday life. It is known based on the response of the students toward the aspects of the overall digital module with an average score of 89.14.

Based on the analysis, it can be concluded that the use of the developed module can improve the ability in associating the concepts of physics with religious values that can be applied in life (Nanto, 'Aini, \& Mulhayatiah, 2017; Suhendi, Mulhayatiah, \& Zakwandi, 2018).

\section{The Problem-Solving Ability of the Students}

The hypothesis test result indicates that there is a difference in the problem-solving ability of the students who use digital modules (experimental class) and those who use PowerPoint (control class) in learning. Before that, we must analyze test precondition such us the normality test and homogeneity test.

Table 2. The Result of the Normality Test

\begin{tabular}{lccccccc} 
& \multicolumn{4}{c}{ Kolmogorov- } \\
& Cl & \multicolumn{3}{c}{ Smirnov } & \multicolumn{3}{c}{ Shapiro-Wilk } \\
& ass & Stat & Df & Sig. & Stat & Df & Sig. \\
\hline Pre- & C & .084 & 30 & $.200^{*}$ & .982 & 30 & .879 \\
test & E & .102 & 30 & $.200^{*}$ & .983 & 30 & .890 \\
Post- & C & .111 & 30 & $.200^{*}$ & .962 & 30 & .343 \\
test & E & .157 & 30 & .059 & .945 & 30 & .123 \\
\hline Source: the output of SPSS processing data, 2018
\end{tabular}

The normality test result indicates that the overall data is significant because sig. of pre-test or post-test is greater than alpha 0.05 and it means that the data is normal. The next test is the homogeneity of the data, the result is presented in table 3.

Table 3. The Result of the Homogeneity Test

\begin{tabular}{llccc} 
& Levene Statistic & $\mathrm{df}_{1}$ & $\mathrm{df}_{2}$ & Sig. \\
\hline Pretest & 3.081 & 1 & 58 & .084 \\
Posttest & 0.23 & 1 & 58 & 0.88 \\
\hline \multicolumn{2}{l}{ Source: the output of SPSS processing data, 2018}
\end{tabular}


Based on table 3, the data is homogeneous because the Sig. of the pretest or post-test is greater than alpha 0.05 . The data have a good of precondition result, the next decisive test is the hypothesis test using t-test calculation. The result is presented in table 4 .

Table 4. The Result of Hypothesis test.

\begin{tabular}{|c|c|c|c|c|}
\hline \multicolumn{2}{|c|}{ Levene's Test for } & \\
\hline \multicolumn{2}{|c|}{$\begin{array}{l}\text { Equality of } \\
\text { Variances }\end{array}$} & \multicolumn{3}{|c|}{ t-test for Equality of Means } \\
\hline $\mathrm{F}$ & Sig. & $\mathrm{T}$ & df & Sig. (2-tailed) \\
\hline 3.081 & 0.084 & 1.957 & 58 & 0.055 \\
\hline 0.023 & 0.880 & -2.891 & 58 & 0.005 \\
\hline
\end{tabular}

Source: the output of SPSS processing data, 2018

Based on t-test result, Ho is accepted, and $\mathrm{Ha}$ is rejected. The difference of the problem-solving skills of experimental class and control class was obtained in accordance with the research that has been done by (Dwi, Arif, \& Sentot, 2013) that there is a significant difference in the problem-solving ability of the computerbased learning compared to the conventional learning. The difference of problem-solving skills between the experimental class and the control class can be seen from the increase in the results of a pre-test, post-test, and N-Gain value.

The improvement of the problemsolving skills is based on the pre-test, posttest, and analysis of N-Gain. The experimental class obtained an average score of 12.83 for prices and 61.41 for posttest. The N-Gain is in the moderate category of 0.56 . This is in accordance with the research conducted by (Simanungkalit, 2016) which discovers that the module can improve the students' problem-solving skills. This result is similar with the result of research by (Pistanty, Sunarno, \& Maridi, 2015) that the Problem-solving ability improvement obtained is in the moderate category that it can enhance the ability to solve problems.
The improved problem-solving ability in the control class seen through pre-test, post-test, and the analysis of N-Gain obtained the average score of 15.47 for pre-test, 50.35 for post-test, and the $\mathrm{N}$ Gain is in the moderate category with the value of 0.41 . The experimental class's problem-solving abilities are improving better than the control class. It can be seen from the N-value Gain of experimental class that is higher than the control class by 0.15 . It can be said that the problemsolving skills by employing the digital module are better compared to the PowerPoint. The results obtained are in accordance with the research that has been done by (Irwandani et al., 2017) that the study by utilizing digital technology can assist students in obtaining a high level of understanding on a concept. Also in line with the results of the (Diani, Yuberti, \& Syarlisjiswan, 2018; Purnamawati et al., 2017; Wahyudi, 2017), the students' problem-solving skills activities should be done collaborative and utilizing procedural thinking exercises that can be the alternative for problem-solving activities. Moreover, teachers can teach the use of various representations in solving physics problems so that the students have a good mastery of concept in physics.

Analysis of problem-solving ability improvement on electromagnetic waves gained the highest $\mathrm{N}$-Gain value is in the experimental class in the polarization concept with a value of 0.64 , and the lowest is on the LCD and LED technology concepts with the value of 0.42 . In the control class, the highest value of the $\mathrm{N}$ Gain on the polarization concept with the value of 0.49 and the lowest value on the concept of interference of electromagnetic with a value of 0.35 . The $\mathrm{N}$-gain of the polarization sub-content is the highest both in control class and experimental class. This is because of the phenomena presented during the learning of polarization concept closely related to daily life so it can be easily understood by 
the students. It is different from LCD and LED technology concepts which $\mathrm{N}$-gain is low in the experimental class. This is because, during the process of learning, the students only used the digital module. They were not collecting references from a variety of learning resources. In the interference material, the control class gets the low value of the N-Gain because the students had difficulty in understanding the concept of interference of light. The student cannot explain how dark and light pattern is formed on a screen. This is in accordance with the research that has been done by (Wibowo et al., 2016) that students often have difficulty describing the phenomenon of interference of light captured on the screen and they often have a misconception about interference associated with photons of electromagnetic waves.

The results of the analysis of $\mathrm{N}$-gain from five aspects of problem-solving ability show that all aspects increased moderately. The aspects of problemsolving skills, especially on the usefulness aspect has the highest value of $\mathrm{N}$-Gain, i.e., 0.62 in experimental class and 0.53 in the control class. This is in accordance with the study done by (Doctor et al., 2016) that the result of the study at the first application of the problem-solving ability test on the students, only the usefulness aspect that could be answered correctly and properly. Based on the results and the discussion, it can be concluded that the use of problem-based digital learning module integrated with religious values on the material of the electromagnetic wave can improve students' problem-solving skills better than PowerPoint.

\section{CONCLUSION}

Based on the results of the research and the discussion, this research can be concluded that: 1) learning achievement of physics learning in class that uses digital modules is better in terms of teacher's activity and students' activity compared to the class that does not use a digital module, 2) the improvement of the problemsolving skills of the students who use digital module is in the moderate category while the problem-solving skills of the student who does not use the digital module increase in the moderate category, and 3 ) there is a difference in the problemsolving skills of the students who use a digital module and the students who do not use a digital module. This is because the phenomena presented during learning through the digital module is closely related to everyday life so that they can be easily understood by students. Strengthened by the results of hypothesis testing, the result shows the value of significance is $<\alpha(0.005<0.05)$, therefore, $\mathrm{Ha}$ is accepted, and $\mathrm{Ho}$ is rejected. Based on the findings of the research, the researchers might give some advice as a consideration in the future that the learning using problem-based digital module integrated with religious values will be more optimal if used individually and the sample questions presented would be better if they are made in the form of the video description.

\section{REFERENCES}

Adams, W. K., \& Wieman, C. E. (2015). Analyzing the many skills involved in solving complex physics problems. American Journal of Physics, 83(5), 459-467.

https://doi.org/10.1119/1.4913923

Akyuz, H. I. H. (2015). Effect of Educational Agent and Its Form Characteristics on Problem Solving Ability Perception of Students in Online Task Based Learning Media. Cypriot Journal of Educational Sciences, 10(3), 265-281.

Ali, M., Sunarno, W., \& Sukarmin. (2013). Pengembangan Modul IPA Berbasis Karakter Islami Melalui Pendekatan Saintifik Pada Tema Rotasi Dan Revolusi Bumi Sebagai Implementasi Kurikulum 2013. Inkuiri: Jurnal 
Pendidikan IPA2, 4(2), 57-67.

Arsyad, A. (2013). Media Pembelajaran. Jakarta: Raja Grafindo Persada.

Artina Jr, A. R., La Rochelle, J. S., Dezee, K. J., \& Gehlbach, H. (2014). Developing questionnaires for educational research: AMEE Guide No. 87. Medical Teacher, 36(6), 463474.

Asyhari, A., \& Silvia, H. (2016). Pengembangan Media Pembelajaran Berupa Buletin dalam Bentuk Buku Saku Untuk Pembelajaran IPA Terpadu. Jurnal Ilmiah Pendidikan Fisika Al-Biruni, 5(1), 1-13. https://doi.org/10.24042/jpifalbiruni. v5i1.100

Christoyadi, S., Widoretno, S., \& Karyanto, P. (2016). Pengembangan Modul Berbasis Kemampuan Pemecahan Masalah pada Materi Sistem Ekskresi untuk Meningkatkan Berpikir Kritis. Inkuiri: Jurnal Pendidikan IPA, 5(1), 74-84.

Diani, R., Yuberti, \& Syarlisjiswan, M. R. (2018). Web-Enhanced Course Based On Problem-Based Learning (PBL): Development Of Interactive Learning Media For Basic Physics II. Jurnal Ilmiah Pendidikan Fisika Al-BiRuNi, 7(1), 105-116. https://doi.org/10.24042/jipfalbiruni. v7i1.2849

Doctor, J. L., Dronfeld, J., Frodemann, E., Heller, K., Hsu, L., Jakson, K. A., \& Yang, J. (2016). Assessing Student Written Problem Solutions: A Problem-Solving Rubric With Application To Introductory Physics. Physical Review Physics Education Research, 12(1), 10130.

Dwi, I. M., Arif, H., \& Sentot, K. (2013). Pengaruh Stategi Problem Based Learning Berbasis ICT Terhadap Pemahaman Konsep dan Kemampuan Pemecahan Masalah Fisika. Jurnal Pendidikan Fisika Indonesia, 9(1).

Fhadhila, F., Ertikanto, C., \& Rosidin, U.
(2018). Developing Student Worksheet of Temperature And Heat Based on Scientific Process Skill. Jurnal Ilmiah Pendidikan Fisika AlBiRuNi, 7(1), 21-32. https://doi.org/10.24042/jipfalbiruni. v7i1.2318

Gao, X.-W., Liu, H.-Y., Xu, B.-B., Cui, M., \& Lv, J. (2018). Element differential method with the simplest quadrilateral and hexahedron quadratic elements for solving heat conduction problems. Numerical Heat Transfer, Part B: Fundamentals, 73(4), 206-224.

Hake, R. R. (2002). Relationship of Individual Student Normalized Learning Gains in Mechanics with Gender, High-School Physics, and Pretest Scores on Mathematics and Spatial Visualization. Physics Education Research Conference, 114. Retrieved from https://scholar.google.com/citations? view_op=view_citation\&hl=en\&user $=10 \mathrm{EI} 2 \mathrm{q} 8 \mathrm{AAAAJ} \&$ citation_for_vie $\mathrm{w}=10 \mathrm{EI} 2 \mathrm{q} 8 \mathrm{AAAAJ}: \mathrm{IjCSPb}-\mathrm{OGe} 4 \mathrm{C}$

Häkkinen, P., Järvelä, S., Mäkitalo-Siegl, K., Ahonen, A., Näykki, P., \& Valtonen, T. (2017). Preparing teacher-students for twenty-firstcentury learning practices (PREP 21): a framework for enhancing collaborative problem-solving and strategic learning skills. Teachers and Teaching, 23(1), 25-41. https://doi.org/10.1080/13540602.20 16.1203772

Irwandani, Latifah, S., Asyhari, A., Muzannur, \& Widayanti. (2017). Modul Digital Interaktif Berbasis Articulate Studio' 13 : Pengembangan pada Materi Gerak Melingkar Kelas X. Jurnal Ilmiah Pendidikan Fisika Al-Biruni, 6(2), 221-231. https://doi.org/10.24042/jipfalbiruni. v6i2.1862

Kemendiknas. (2006). Permendiknas No. 23 Tahun 2006. Depertemen 
Pendidikan Dan Kebudayaan.

Kemendiknas. (2010). Panduan Pengembangan Bahan Ajar Berbasis TIK. Depertemen Pendidikan Dan Kebudayaan.

Li, Y. W. (2016). Transforming Conventional Teaching Classroom to Learner-Centred Teaching Classroom Using Multimedia-Mediated Learning Module. International Journal of Information and Education Technology, 6(2), 105112.

https://doi.org/10.7763/IJIET.2016.V 6.667

Lomax, R. G. (2000). An Introduction to Statistical Concepts for Education and Behavioral Sciences. New York: Lawrence Erlbaum Associates.

Malik, A. (2015). Model Problem Solving Laboratory To Improve Comprehension The Concept Of Students. In Proceeding International Seminar on Mathematics, Science, and Computer Science Education (MSCEIS) 2015 (pp. 43-48). Faculty of Mathematics and Science Education Universitas Pendidikan Indonesia.

Marshman, E., \& Singh, C. (2015). Student difficulties with quantum states while translating state vectors in Dirac notation to wave functions in position and momentum representations. asXiv Preprint arXiv, 1509(4084).

Mayasari, T., Kadarohman, A., \& Rusdiana, D. (2016). Apakah Model Pembelajaran Problem Based Learning dan Project Based Learning Mampu Melatih Keterampilan Abad 21. Jurnal Pendidikan Fisika Dan Keilmuan (JPFK), 2(1), 48-55.

McClean, S., Attardi, S. M., Faden, L., \& Goldsmidt, M. (2016). Flipped classrooms and student learning: not just surface gains. Advance in Physichology Education, 40(1), 4755.
Mirkouei, A., Bhinge, R., McCoy, C., Haapala, K. R., \& Dornfeld, D. A. (2016). A Pedagogical Module Framework to Improve Scaffolded Active Learning in Manufacturing Engineering Education. In Procedia Manufacturing 5, 1128-1142.

Munadi, Y. (2012). Media Pembelajaran. Jakarta: Gaung Persada Press.

Myerson, J., Baumann, Ana, A., \& Green, L. (2014). Discounting of delayed rewards: theoretical interpretation of the Kirby questionnaire. Behavioural Processes, 107, 99-105.

Nanto, D., 'Aini, A. N., \& Mulhayatiah, D. (2017). Android worksheet application based on discovery learning on students' achievement for vocational high school: Mechanical behavior of materials topics. In AIP Conference Proceedings (Vol. 1848, p. 50006). AIP Publishing.

Ngalim, P. (2008). Prinsip-prinsip dan Teknik Evaluasi Pengajaran. Bandung: Remaja Rosdakarya.

Nurhidayanti, S., Tayeb, T., \& Abbas, B. (2017). Pengembangan Bahan Ajar Matematika Berbasis Masalah untuk Memfasilitasi Pencapaian Kemampuan Penalaran pada Pokok Bahasan Perbandingan Kelas VII MTsN Model Makassar. MaPan: Jurnal Matematika Dan Pembelajaran, 5(2), 236-250.

Nurjanah, J. R. (2014). Pengembangan Media Pembelajaran Interaktif EMagazine Pada Materi Pokok Dinamika Rotasi untuk SMA Kelas XI. Jurnal Materi Dan Pembelajaran Fisika, 4(1).

Pistanty, M. A., Sunarno, W., \& Maridi, M. (2015). Pengembangan Modul IPA Berbasis Problem Based Learning Untuk Meningkatkan Kemampuan Memecahkan Masalah Pada Materi Polusi Serta Dampaknya Pada Manusia Dan Lingkungan Siswa Kelas XI Smk Pancasila Purwodadi. INKUIRI: Jurnal 
Pendidikan IPA, 4(2), 68-75.

Prastowo, A. (2011). Panduan Kreatif Membuat Bahan Ajar Inovatif. Yogyakarta: Diva Press.

Purnamawati, D., Ertikanto, C., \& Suyatna, A. (2017). Keefektifan Lembar Kerja Siswa Berbasis Inkuiri untuk Menumbuhkan Keterampilan Berpikir Tingkat Tinggi. Jurnal Ilmiah Pendidikan Fisika Al-Biruni, 6(2), 209-219. https://doi.org/10.24042/jipfalbiruni. v6i2.2070

Ruipérez-Valiente, J. A., Muñoz-Merino, P. J., Leony, D., \& Kloss, C. D. (2015). ALAS-KA: A learning analytics extension for better understanding the learning process in the Khan Academy platform. Computers in Human Behavior, 47, 139-148.

Rusilowati, A. (2007). Diagnosis Kesulitan Belajar Fisika Siswa SD, SMP, dan SMA dengan Teknik General Diagnostic dan Analytic Diagnostik. In Seminar Nasional MIPA. Yogyakarta.

Simanungkalit, R. H. (2016). Pengembangan Perangkat Pembelajaran untuk Meningkatkan Kemampuan Pemecahan Masalah Matematis Siswa SMP Negeri 12 Pematangsiantar. MUST: Journal of Mathematics Education, Science and Technology, 1(1), 39-56.

Suhendi, H. Y., Mulhayatiah, D., Yuningsih, E. K., Malik, A., Fauziah, R., \& Ardiansyah, R. (2018). Development of Student Worksheet Based on a Scientific Approach for Rotational Dynamics Concept. In Proceedings of the International Conference on Islamic Education (ICIE 2018) (Vol. 261, pp. 102-106). Atlantis Press.

Suhendi, H. Y., Mulhayatiah, D., \& Zakwandi, R. (2018). The Effectiveness of Worksheet Based Learning of Rotational Dynamics on
Students' Critical Thinking Skills Viewed from IQ Score. Scientiae Educatia: Jurnal Pendidikan Sains; $7(1)$.

Suhendi, H. Y., Ramdhani, A. M., \& Irwansyah, F. S. (2018). Verification Concept of Assesment for Physics Education Student Learning Outcome. International Journal of Engineering \& Technology, 7(3), 321-325. https://doi.org/DOI: 10.14419/ijet.v7i3.21.17181

Sujarwanto. (2014). Kemampuan Pemecahan Masalah Fisika Pada Modeling Instruction Pada Siswa SMA Kelas XI. Jurnal Pendidikan IPA Indonesia, 3(1), 65-78.

Wahyudi, I. (2017). Pengembangan Program Pembelajaran Fisika SMA Berbasis E-Learning dengan Schoology. Jurnal Ilmiah Pendidikan Fisika Al-BiRuNi, 6(2), 187-199. https://doi.org/10.24042/jipfalbiruni. v6i2.1850

Wibowo, F. C., Suhandi, A., Rusdiana, D., Darman, D. R., Ruhiat, Y., Denny, Y. R., Fatah. (2016). Microscopic Virtual Media ( MVM ) in Physics Learning: Case Study on Students Understanding of Heat Transfer Microscopic Virtual Media ( MVM ) in Physics Learning: Case Study on Students Understanding of Heat Transfer. Journal of Physics: Conference Series, 739, 1-6. https://doi.org/10.1088/17426596/739/1/012044

Zakwandi, R., Zannah, N., \& Irawan, I. (2017). Analisis Konsep Pesawat Sederhana Pada Pembelajaran Ilmu Pengetahuan Alam Berbasis Tradisi Sains Islam Di Madrasah Tsanawiyah. Jurnal Pendidikan Islam Belajea, 2(1), 21-34. https://doi.org/http://dx.doi.org/10.29 240/bjpi.v2i1.269 